\title{
THE INFLUENCE OF INDIVIDUAL AND ENVIRONMENTAL FACTOR TO THE ORGANIC RICE FARMING PERFORMANCE AND ENTREPRENEURIAL BEHAVIOUR AS MEDIATION VARIABLES
}

\author{
Amrita*, Marwanti Sri, Irianto Heru \\ Master of Agribusiness, Universitas Sebelas Maret, Surakarta, Indonesia \\ *E-mail: amritaalmeira@gmail.com
}

\begin{abstract}
This research is aimed to reveal the factors that influence the entrepreneurial behaviour of organic rice farmers and also the influence of intrepreneurial behaviour towards the performance of organic rice farming in Sragen Regency, Central Java Province, Indonesia. This research uses Structural Equation Modeling supported by the software AMOS 22.0 as a tool to analysing. This research uses purposive sampling which includes 150 farmers who commit to organic rice farming. The results of this research show all the hypothesis is valid. There are positive influences of individual factors towards entrepreneurial behaviour, environmental factors towards the entrepreneurial behavior and the performance of rice farming, and entrepreneurial behaviour towards the farm business performance of organic rice farming.
\end{abstract}

\section{KEY WORDS}

Individual factor, environmental factor, entrepreneurial behaviour, farming performance, organic farming.

An organic farming is a method of agriculture cultivation which uses natural chemical and avoids the use of synthetic chemical. The main goal of cultivating the organic rice farming is to provide agriculture products which are free of chemical substance especially for the products of food which are safe for both consumer and producer (Mubiar \& Alik, 2014). Organic farming can also promote the healthy environment. The organic rice is one of the products of organic farming cultivation. Sragen regency has potential production of organic rice. However, there are issues and challenges related to organic rice farming in Sragen regency. These challenges are related to the technology for providing production facilities such as organic fertilizer and organic pesticides and also the poor marketing strategies. Hence, supportive human resources are needed to support those phenomenons (Alfiani, 2014).

Human resource development in agriculture or agribusiness entrepreneur is the main priority that must be taken as a serious issue. It is because human resource plays important roles in planning, implementing, and bearing the production risks, moreover human also can manage the decision to adopt or postpone the application of a technology to get the added value (Pambudi \& Dabukke, 2010). Human resource also has important roles in the achieving competitive advantage as stated by Krisnamurthi (2001). He has argued that individual factor can determine the success of achieving competitive advantage because every soul has creativity, innovation, ability, and also courage. He also believes that every individual can take advantage of the opportunity and use it to further the skill not to mention to overcome difficulites. Furthermore, human also have the ability to control and utilize technology so that those can help human to discover financial capital, information and also business networking. Thus, human resource has important roles in developing business.

The application of entrepreneurial behaviour to the organic rice farmers is conducted to give positive impact to the farm business performance. The entrepreneurial behaviour will make the farmers become more active in utilizing and developing the business potential, innovative in the production process, and also bold to take the business' risks so that it will give impacts to the performance of the farmers (Santoso et al, 2015). Another expert highlights that the entrepreneurial behaviour, somehow, can upgrade the business 
performance and make the farmers become innovative in utilizing the resources they have more efficient (Grande et al, 2012).

This research is executed to further analyze the individual factor and environmental factor which influence the entrepreneurial behaviour of organic rice farmers and also analyze the entrepreneurial behaviour influence towards the organic rice farming performance in Sragen Regency.

\section{LITERATURE REVIEW}

The skill of entrepeneurship can be determined as the function of entrepreneurial behaviour in combining creativity, innovation, the hard working, and also courage to get the opportunities and successful in business (Suryana, 2003). Yuyun (2011) has concluded that a company which proposes entrepreneurial behaviour by implementing innovative designs of production can improve business performance. It can be done by minimizing the costs or preventing the rising costs and maximizing the output. Such company has succeeded in business due to a combination of new input which produces the greater output compared with the previous one. In addition, by implementing innovative idea, certain company can even produce the efficient use of inputs so that it can reduce production cost to improve company profits and growth.

The general model of entrepreneurial behavior and business performance proposed by Delmar consists of business performance, entrepreneurial behaviour, individuals (motivation and ability) and the environmental. This model is based on the theory of Interactionist Perspective which means the behavior is assumed based on the reciprocal influence between business performance, individuals and the environmental. Meanwhile, the business performance depends on the factor of entrepreneurial behavior. This research also combines the psychological performance theory because the main focus of this research is to explain how entrepreneurial behavior affects business performance (Delmar, 1996).

The factors that may affect the entrepreneurial behaviour are individual factors and environmental factor. The individual factor as stated by (Zainura et al, 2016) consists of age, education, experience, and motivation. The environmental factor may consist of financial capital, family, and also social environment. (Virginia \& Carlos, 2012) have said that the individual factors can influence the intention of developing the business. In the context of micro business, the psychological characteristics tend to dominate a person to behave in entrepreneurial culture and this is the primary motivation of starting a business and selfefficacy. The explanation above shows how individual factor and environmental factor can affect someone's behaviour. Kuratko et al, (2014) and Rosairo \& David Potts (2016) have stated that to know the environmental factors influencing entrepreneurial activities, it is necessary to examine the individual factor. Meanwhile, individual factor of organizational members and organizational environmental factors will influence entrepreneurial behavior which will ultimately affect the organizational performance strategies needed for organizational success. farmers.

$\mathrm{H1}$ : Individual factor significantly influences the entrepreneurial behavior of organic rice rice farmers.

H2: Environmental factor significantly influences entrepreneurial behavior of organic

Entrepreneurial behaviour is related to the human's behaviour to identify and take the opportunities for business formation and development, as well as to explore and create opportunities in the on-going business activities (Rosairo \& David Potts, 2016) through actions that lead to the entrepreneurial concepts; creative, innovative, and risk-taking (Delmar, 1996). The entrepreneurial behaviour gives positive impact to someone's performance. This hypothesis corresponds to the previous research done by Delmar (1996). The other researchers such as Chen et al (2011); Roach et al (2016) and Odermi (2011) have also stated that the entrepreneurship gives positive impact towards business development and business performance. Improving business performance is influenced by 
entrepreneurial behavior such as being proactive, competitive, innovative, risk-taking, and independent (Doye \& Bwisa, 2015).

H3: The entrepreneurial behavior of organic rice farmers significantly affects the performance of organic rice farming.

In the model of entrepreneurial behaviour and business performance proposed by Delmar, the environmental factor is seen as a control variable and it is not considered as the main object of the research. Somehow, the environmental factor directly gives impact to the business performance (Dharmaratne, 2012; Schjoedt \& Kraus, 2009; Chen et al., 2011). The company's performance depends on the environment because the business will run, if there is a demand for goods and services offered by the company (Delmar, 1996). According to Gomezelj \& Kušce (2013), the environmental factors such as financial assistance, government policy, training support, business infrastructure, market competitiveness, and social cultural norms significantly affect the business performance. farming.

$\mathrm{H} 4$ : Environmental factor has significant effect on the performance of organic rice

\section{METHODS OF RESEARCH}

Methods of data analysis used in this research are Structural Equation Modeling (SEM) supported by the software AMOS 22.0. Data processing analyzed by Structural Equation Modeling (SEM) are as follows: the validity and reliability, assumption of adequacy of the sample, the assumption of normality, the assumption of outliers, Evaluation of Goodness-ofFit, and hypothesis testing. The technique used in this research is techniques of survey by employing the questionnaire as a tool for data collection. The determination of the location was carried out by means of purposive with the consideration that Sragen has been the pioneer of organic rice farming since 2001 and received the organic certification and labelling from INOFICE (Indonesian Organic Farming Certification). In addition, the organic rice is one of the featured products in Sragen regency. The population of the research is the farmers who cultivate the organic rice in Sragen regency. The sample of the research is 150 respondents.

\section{RESULT OF STUDY}

The characteristics of respondents can be further seen at the table 1 . All the respondents are mostly male, which is $78.67 \%$. Most organic rice farmers are in the productive age (41-60 y.o) which is $52.67 \%$. The education level of the respondents is still low because most of the farmers are only graduated from elementary school $(59.33 \%)$. Meanwhile, only $1.33 \%$ respondents have education at the college level. The land area of organic rice farming is mostly in the range of $1.000 \mathrm{~m}^{2}-3.000 \mathrm{~m}^{2}(43.33 \%)$, while the land area which is more than $9.000 \mathrm{~m}^{2}$ is only $10.67 \%$. At the level of land area, the survey indicates that organic rice farming is executed on small scale business which will ultimately affect the farmer's income. Based on the data information of the respodents, only $32.67 \%$ of the respondents have basic income of organic rice farming of $<$ Rp.6.000.000, - for each cropping season. Low income levels of organic rice farmers can be caused by the land area which tends to be narrow. The farmers who have wider land area tend to have high income compared with the other farmers who only have land area in the range of $1.000 \mathrm{~m}^{2}-3.000 \mathrm{~m}^{2}$.

In statistic analysis used AMOS 22.0, the research can be started by testing the validity and reliability construct to measure the ability level of research instrument. This, somehow, can reveal whether the data are appropriate with research problem. An item considered as a valid and widely accepted if the factor loading is more than 0.5 while the ideal one is more than 0.7 (Ghozali I, 2014). The formal education construct has the factor loading 0.083 . This construct is not considered as valid so it has to be dropped out from the model. Based on the calculation of AVE and CR, all the constructs have the AVE $>0.5$ and CR $>0.7$. It means all the constructs have met the demand of reliability construct. Based on the normality testing, this model of c.r multivariate is -1.786 . The c.r multavariate is on the range $-2.58<z<2.58$ 
which means SEM model in this research has met the criteria of normality assumption. None of the mahalonobis distance of the entire sample exceed more than 43.8202 (Chi Square at $\alpha=0.001$ and $d f=19)$. This means the data being analyzed does not contain the outliner.

Table 1 - Respondent's characteristic

\begin{tabular}{|l|l|l|l|l|l|}
\hline Characteristics & $\mathrm{N}$ & $\%$ & Characteristics & $\mathrm{N}$ & $\%$ \\
\hline Sex & - & - & Land area & - & - \\
\hline Male & 118 & 78.67 & $1000 \mathrm{~m}^{2}-3000 \mathrm{~m}^{2}$ & 65 & 43.33 \\
\hline Female & 32 & 21.33 & $3001 \mathrm{~m}^{2}-5000 \mathrm{~m}^{2}$ & 41 & 27.33 \\
\hline Age & - & - & $5001 \mathrm{~m}^{2}-7000 \mathrm{~m}^{2}$ & 14 & 9.33 \\
\hline $18-40$ & 21 & 14.00 & $7001 \mathrm{~m}^{2}-9000 \mathrm{~m}^{2}$ & 14 & 9.33 \\
\hline $41-60$ & 79 & 52.67 & $>9000 \mathrm{~m}^{2}$ & 16 & 10.67 \\
\hline$>60$ & 50 & 33.33 & Rice farming Income & - & - \\
\hline Education's degree & - & - & $>$ Rp.6.000.000,- & 49 & 32.67 \\
\hline Not going to school & 1 & 0.67 & Rp.6.000.000-Rp.12.999.999 & 44 & 29.33 \\
\hline SD (Elementary School) & 89 & 59.33 & Rp. 13.000.000 - Rp.18.999.999 & 21 & 14.00 \\
\hline SMP (Junior High School) & 38 & 25.33 & Rp. 19.000.000 - Rp.24.999.999 & 19 & 12.67 \\
\hline SMA (Senior High School) & 20 & 13.33 & $>$ Rp. 24.000.000,- & 17 & 11.33 \\
\hline Diploma/ Sarjana (Bachelor) & 2 & 1.33 & - & - & - \\
\hline
\end{tabular}

Table 2 - Validity and Reliability Construct

\begin{tabular}{|c|c|c|c|}
\hline Indicator & Factor loading & $\operatorname{AVE}(>0,5)$ & $\mathrm{CR}(>0,7)$ \\
\hline Individual Factor (FI) & & \multirow{5}{*}{0.829} & \multirow{5}{*}{0.882} \\
\hline Formal Education & 0.083 & & \\
\hline Farming experience & 0.894 & & \\
\hline Motivation & 0.933 & & \\
\hline Perception & 0.906 & & \\
\hline \multicolumn{2}{|l|}{ Environmental Factor (FL) } & \multirow{8}{*}{0.682} & \multirow{8}{*}{0.971} \\
\hline Input availability & 0.838 & & \\
\hline Training and Elucidation's support & 0.815 & & \\
\hline Capital and production tools support & 0.831 & & \\
\hline Promotion and Marketing support & 0.812 & & \\
\hline Business regulation support & 0.827 & & \\
\hline Compactness of farmers & 0.859 & & \\
\hline Access to market information & 0.788 & & \\
\hline \multicolumn{2}{|l|}{ Enterpreneurial Behavior (PK) } & \multirow{6}{*}{0.789} & \multirow{6}{*}{0.952} \\
\hline Innovative & 0.862 & & \\
\hline Risk-Taking & 0.895 & & \\
\hline Hard working & 0.907 & & \\
\hline Respond to opportunities & 0.897 & & \\
\hline Independent & 0.861 & & \\
\hline \multicolumn{2}{|l|}{ Farming Performance $(\mathrm{KU})$} & \multirow{5}{*}{0.819} & \multirow{5}{*}{0.929} \\
\hline Income level & 0.901 & & \\
\hline Level marketing area expansion & 0.926 & & \\
\hline Ability to compete & 0.898 & & \\
\hline Farming commitment & 0.887 & & \\
\hline
\end{tabular}

Evaluating the goodness of fit means measuring the concord level between the models being hypothesized with the data provided. The goodness of fit testing is conducted to refer the fitness index.

The table 3 shows how the data is processed. The total value of X2 is 199.316 with the probability 0.003 . Basically, if the Chi-Square being calculated is small and the $p$ value does not exceed more than 0.05 , it is required to use other criterias of goodness of fit (Ghozali, 2004). The GFI (Goodness of Fit Index) is under the reference value, 0.880 . However, all the values at the table 3 are nearly closed to the reference value so that they can be considered as marginally fit. These results indicate that the model's goodness of fit was reative good and could be condidered as meeting the model's suitability.

The result of the research indicates the entire hypothesis can be accepted and valid. $\mathrm{H} 1, \mathrm{H} 3$, and $\mathrm{H} 4$ are valid at the significant level of $\alpha 0.001$ while $\mathrm{H} 2$ is valid at the significant level of a 0.01 . 


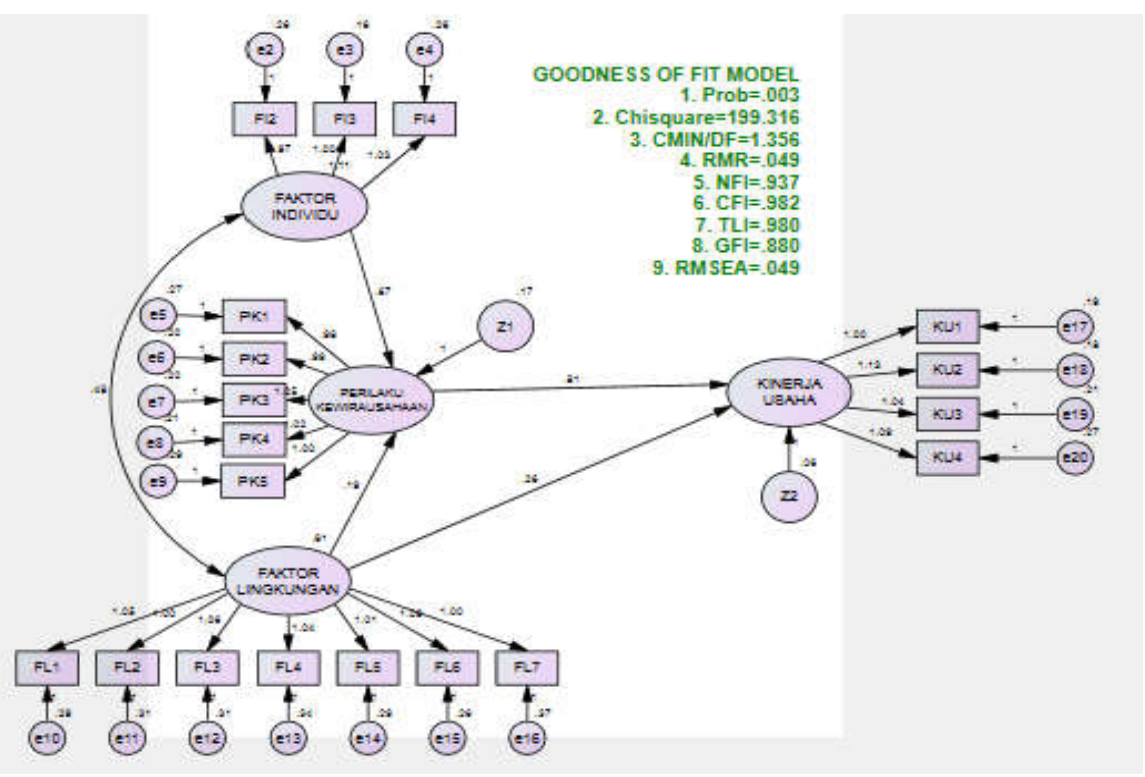

Figure 1 - Structural Model

Table 3 - Result of evaluation Goodness of Fit

\begin{tabular}{|l|l|l|l|l|}
\hline No. & Index & Reference Value & Result & Evaluation \\
\hline 1. & Chi Square $\left(\mathrm{X}^{2}\right)$ & Small expected & 199.316 & Poor fit \\
\hline 2. & Probability & $>0.05$ & 0.003 & Poor fit \\
\hline 3. & CMIN/DF & $<2$ & 1.356 & Good fit \\
\hline 4. & RMSEA & $\leq 0.08$ & 0.049 & Good fit \\
\hline 5. & RMR & $<0.05$ & 0.049 & Good fit \\
\hline 6. & GFI & $\geq 0.90$ & 0.880 & Marginal fit \\
\hline 7. & TLI & $\geq 0.90$ & 0.980 & Good fit \\
\hline 8. & NFI & $\geq 0.90$ & 0.937 & Good fit \\
\hline 9. & CFI & $\geq 0.90$ & 0.982 & Good fit \\
\hline
\end{tabular}

Table 4 - Result of Hypothesis Testing

\begin{tabular}{|l|l|l|l|l|l|}
\hline Hypothesis & Variable & Estimate & S.E. & C.R. & P \\
\hline $\mathrm{H} 1$ & $\mathrm{PK} \leftarrow \mathrm{FI}$ & 0.651 & 0.062 & 10.429 & ${ }^{* * *}$ \\
\hline $\mathrm{H} 2$ & $\mathrm{PK} \leftarrow \mathrm{FL}$ & 0.199 & 0.071 & 2.822 & $0.005^{* *}$ \\
\hline $\mathrm{H} 3$ & $\mathrm{KU} \leftarrow \mathrm{PK}$ & 0.810 & 0.064 & 12.622 & ${ }^{* * *}$ \\
\hline $\mathrm{H} 4$ & $\mathrm{KU} \leftarrow \mathrm{FL}$ & 0.278 & 0.057 & 4.842 & $*^{* * *}$ \\
\hline
\end{tabular}

Note: ${ }^{* * *}$ significant level at $\alpha 0.001 ;{ }^{*}$ significant level at $\alpha 0.05 ;{ }^{* *}$ significant level at $\alpha 0.01$.

\section{DISCUSSION OF RESULTS}

The result of the study shows the average response of the farmers is 3.43 . It indicates that all the responses can give explanation about personal quality of the farmers in doing the business. It is because the everage experience in organic rice farming is mostly 12 years. The farmers have motivation to get prosperous life in family by cultivating organic rice farming. However, farmers have edequate belief of success in developing the organic rice farming because of the lack of capital. All the capitals are used to fulfil the daily need and fund the next planting.

In addition, the result of this study shows there is a positive influence between individual factors $(\mathrm{FI})$ and the entrepreneurial behavior $(\mathrm{PK})$. It is indicated by the probability value $(P)$ which is smaller than the value of $\alpha 0.001$, with an estimate value of 0.651 . High estimation values indicate that the individual factor has big influence to the entrepreneurial behaviour of organic rice farmers. The individual factor can be used as a prediction model to predict the entrepreneurial behaviour. It means the more experience they have, the higher 
motivation and perception they get in developing organic rice farming. Those will ultimately advance the entrepreneurial behaviour of farmers in organic rice farming.

The finding results above are in accordance with the previous research done by Rosairo \& David Potts (2016); Virginia \& Carlos (2012); and Gomezelj \& Kušce (2013). All of their research show the significant influence of individual factor to the entrepreneurial behaviour. Based on this finding, it can be said that individual factor affects the entrepreneurial behaviour of the majority of respondents. This condition represents that the respondents have possibility to improve the performance of organic rice farming. This individual factor can be brought up because of the length of experience of organic rice farming, the great motivation of the farmers to improve the prosperous life of the family and the perception of farmers about belief of success in developing the organic rice farming.

In addition, the result of this study also shows the calculation number is at the point 3.70. It means all the respondents agree that the environmental factor can support the performance of organic rice farming. All the respondents have said that they have obtained the availability of inputs such as seeds, organic fertilizers and pesticides, the government support in counselling, training, promotion and marketing, and business regulation. This, more or less, gives influence to the organic rice farming. However, there is still obstacle in conducting the organic rice farming in Sragen regency. Financial assistance program of the goverment is unevenly distributed. Not all the farmers even gets the financial assistance but they show the compactness by helping each others when planting and cropping the organic rice. Meanwhile, the farmers admitted that they get information and also business networking from agricultural extension officers, collectors, public figure, and also the fellow farmers.

Based on the hypothesis testing, the environmental factor ( $F L)$ gives positive influence to the entrepreneurial behaviour (FL). It is indicated by the probability value which is less than $\alpha 0.01$ and positive correlation with the estimate value 0.199 . This means that the high level of availability of inputs such as (1) government support in conducting counseling or training, (2) financial assistance and production facilities, (3) promotion and marketing, (4) business regulation, (5) compactness of farmers, and (6) an easy access to business networking for organic rice farming, all of them, can even give positive impacts to the entrepreneurial behaviour of the farmers. This result of study is supported by the previous research done by Shah Ali \& Tariq Bhutta (2013); Rosairo \& David Potts (2016); and Doye \& Bwisa (2015). Those researchers have commited a study to reveal the relation between environmental factor and entrepreneurial behaviour. It is confirmed that there is positive relation between FL (environmental factor) and entrepreneurial behaviour (PK).

The result of the hypothesis testing also signifies that there is significant influence of entrepreneurial behaviour (PK) to the performance of organic rice farming (KU). The probability value $(P)$ is smaller than $\alpha 0.001$, with the estimate value 0.810 . It means that the higher entrepreneurial behaviour possessed by farmers, the higher organic rice farming performed by the farmers. By this, the farmers are expected to enhance the success of businesses in the organic rice farming sector. The result of this study also indicates that the level of innovation, risk-taking, hard-working, responsive to opportunity, independence will ultimately affect the enhancement of organic rice farming performance. The good entrepreneurial behaviour can give implication to the basic performance of the farming such as increasing the revenue, marketing area, competitiveness, and also commitment of farming.

A research done by Roach et al., (2016) shows there is positive influence between entrepreneurial behaviour and business performance. It is widely accepted that the research proposed by Roach et al., (2016), et al is done to know the influence of the entrepreneurial factor to the business performance. Meanwhile, innovation becomes the primary factor to improve the business performance. In rhythm with the research done by David C, et al, this study also signifies the positive relation between innovation and the business performance. By implementing innovative designs and ideas, a company can produce and develop the products, improve the services to upgrade the business performance. Other researchers who have conducted the similar research are Odermi (2011); Shah Ali \& Tariq Bhutta (2013); 
Chen et al., (2011); and Doye \& Bwisa (2015). All of them have described the positive influences of entrepreneurial behaviour to the business performance.

Based on the hypothesis testing, it can be confirmed that there is positive impact between environmental factor (FL) and farm business performance (KU). It is indicated by the probability value $(p)$ which shows the lower scale than $\alpha 0.001$, with the estimate value 0.278. This means the higher environmental factor that farmers have, the higher farming business performed by the farmers. In addition, the higher environmental factor that affects the organic rice farmers will directly give impact to the improvement of business performance of farming. It can give improvements in some aspect of the business performance such as the increased of the revenue, the wider marketing area, great competitiveness, and also higher commitment of farming. This result is supported by the previous research that analyzed the influence of environmental factors to the business performance of farming. These researches done by Chen et al., (2011); Dharmaratne (2012); and Gomezelj \& Kušce (2013).

\section{CONCLUCION AND SUGGESTIONS}

Individual factor and environmental factor, both of them, give positive influences to the entrepreneurial behaviour of organic rice farming. The entrepreneurial behaviour directly gives positive impact to the organic rice farming performance. In addition, Environmental factor significantly affects the performance of organic rice farming. Majority of organic rice farmers have low education level so it is necessary to take them into non-formal education such as giving them an in-house training. It is to help the farmers to get easy in adopting and utilizing technology for the good farm business performance. Moreover, the financial capital, obviously influence the entrepreneurial behaviour. Sufficient financial capital is needed to support the entrepreneurial behaviour so that it can help to increase the basic performance of the farmers. Almost all the farmers can detect the opportunities they have. However, only few farmers take advantage of the opportunity because of the lack of financial capital.

\section{REFERENCES}

1. Alfiani, R. (2014). Model Peningkatan Kinerja Melalui Pembelajaran Organisasi dan Pembentukan Modal Insani pada Gapoktan Sri Makmur, Kabupaten Sragen. Institut Pertanian Bogor.

2. Chen, K.-H., Yien, J.-M., Huang, K.-P., \& Huang, C.-J. (2011). Performance and its Link to Entrepreneurial Behavior. American Journal of Applied Sciences, 8(7), 703-707.

3. Delmar, F. (1996). Enterpreneurial Behaviuor and Business Performance. Management. Stockhlom School of Economic.

4. Dharmaratne, K. L. B. G. (2012). Impact of Individual Factors on the Business Performance of Women Entrepreneurs in Sri Lanka . Sabaragamuwa University Journal, 11(1), 139-165.

5. Doye, N. C., \& Bwisa, M. (2015). The Relationship Between Entrepreneurial Behavior And Performance Of Camel Rearing Enterprises In Turkana County , Kenya. International Journal of Technology Enhancements and Engineering Research, 3(09), 149-157.

6. Ghozali I. (2014). Model Persamaan Struktural Konsep dan Aplikasi dengan Program AMOS 22.0. Semarang: Badan Penerbit Universitas Diponegoro.

7. Gomezelj, D. O., \& Kušce, I. (2013). The influence of personal and environmental factors on entrepreneurs' performance. Kybernetes, 42(6), 906-927. https://doi.org/10.1108/K08-2012-0024

8. Grande, J., E Medsen, \& OJ Borch. (2012). The relationship between resources, entrepreneurial orientation and performance in farm-based ventures. International Journal of Enterpreneurship and Regional Development, 23(3-4).

9. Krisnamurthi, B. (2001). Agribisnis. Bogor: Yayasan Pengembangan Sinar Tani.

10. Kuratko, D. F., Hornsby, J. S., \& Jeffrey G, C. (2014). Diagnosing a firm's internal 
environment for corporate entrepreneurship. Business Horizons, 57(1), 37-47. https://doi.org/10.1016/j.bushor.2013.08.009

11. Mubiar, P., \& Alik, S. (2014). Padi SRI Organik Indonesia. Jakarta: Penebar Swadaya.

12. Odermi, A. (2011). Corporate entrepreneurship and strategy process: A performance based research on Istanbul market. Procedia - Social and Behavioral Sciences, 24, 611626. https://doi.org/10.1016/j.sbspro.2011.09.068

13. Pambudi, R., \& Dabukke. (2010). Refleksi Agribisnis. Bogor: IPB Press.

14. Roach, D. C., Ryman, J. A., \& Joyline, M. (2016). Effectuation, innovation and performance in SMEs: an empirical study. European Journal of Innovation Management, 19(2), 214-238. https://doi.org/10.1108/EJIM-12-2014-0119

15. Rosairo, R., \& David Potts. (2016). A study on entrepreneurial attitudes of upcountry vegetable farmers in Sri Lanka. Journal of Agribusiness in Developing and Emerging Economies, 6(1), 39-58. https://doi.org/10.1108/JADEE-07-2014-0024

16. Santoso, E., Fajar, R., \& Roza, Y. (2015). ANALISIS PERILAKU WIRAUSAHA DAN KINERJA USAHA (Studi Pada Usaha Agroindustri di Kota Pekanbaru) ENTREPRENEURIAL BEHAVIOR AND PERFORMANCE ANALYSIS EFFORT (Study On Agro-Industries In The City Of Pekanbaru), 2(1).

17. Schjoedt, L., \& Kraus, S. (2009). Entrepreneurial teams: definition and performance factors. Management Research News, 32(6), 513-524. https://doi.org/10.1108/01409170910962957

18. Shah Ali, S. Z., \& Tariq Bhutta, N. (2013). Corporate Entrepreneurship and Agency Cost: A Theoretical Perspective *. Open Journal of Accounting, 2(July), 79-86. https://doi.org/10.4236/ojacct.2013.23010

19. Suryana. (2003). Kewirausahaan: Pedoman Praktis, Kiat, dan Proses Menuju Sukses (Pertama). Jakartam: Salemba Empat.

20. Virginia, B.-S., \& Carlos, A.-S. (2012). Entrepreneurial behaviour, impact of motivation factors on decisions to creat new ventures. Investigaciones Europeas de Dirección y $\begin{array}{llll}\text { Economía de La 18 } & \text { Empresa, } & \text { 18:132-8. }\end{array}$ https://doi.org/http://dx.doi.org/10.1016/S1135-2523(12)70003-5

21. Yuyun, W. (2011). Ekonomika Kewirausahaan. Buletin Manajemen Kewirausahaan, 124.

22. Zainura, U., Kusnadi, N., \& Burhanuddin. (2016). Perilaku kewirausahaan petani kopi arabika gayo di Kabupaten Bener Meriah Provinsi Aceh. Jurnal Penyuluhan, 12(2), 129130. 